\title{
ANALISIS KINERJA KEUANGAN LAPORAN REALISASI ANGGARAN PENDAPATAN DAN BELANJA DAERAH KOTA BOGOR TAHUN 2014-2019
}

\author{
Rika Silvianingsih ${ }^{1}$, Utpala Rani $^{2}$ \\ ${ }^{1,2}$ Universitas Tidar, Indonesia \\ E-mail: ${ }^{1)}$ rikasilvia18@gmail.com, ${ }^{2)}$ utpala@untidar.ac.id
}

\begin{abstract}
Abstrak
Tujuan dilakukan penelitian ini untuk mengetahui kinerja keuangan Kota Bogor tahun 2014 sampai dengan tahun 2019 berdasarkan perhitungan lima rasio, yaitu: rasio kemandirian, rasio, derajat fiskal, rasio ketergantungan keuangan daerah, rasio efektivitas pendapatan asli daerah, dan rasio efesiensi keuangan daerah. Jenis penelitian dilakukan dengan penelitian kuantitatif dan data yang digunakan yaitu data sekunder yang diambil dari ppid.kotabogor.go.id. Hasil penelitian ini menunjukan bahwa kinerja keuangan pada Kota Bogor sudah baik jika ditinjau dari Rasio Kemandirian Keuangan Daerah, Rasio Efektivitas Pendapatan Asli Daerah, dan Rasio Derajat Desentralisasi Fiskal, akan tetapi untuk Rasio Ketergantungan Keuangan Daerah kurang mengoptimalkan pendapatan dari sektor lain sehingga tingkat ketergantungan akan dana transfer masih sangat tinggi dan Rasio Efisensi kurang efisien karena lebih besarnya belanja daerah daripada pendapatan daerah yang diterima.
\end{abstract}

Kata Kunci: Realisasi Anggaran, Kinerja Keuangan, APBD

\begin{abstract}
The purpose of this study was to determine the financial performance of Bogor City from 2014 to 2019 based on the calculation of five ratios, namely: independence ratio, ratio, fiscal degree, regional financial dependence ratio, effectiveness ratio of local revenue, and regional financial efficiency ratio. This type of research is carried out by quantitative research and the data used are secondary data taken from ppid.kotabogor.go.id. The results of this study indicate that the financial performance of the city of Bogor is fine when measured by the Regional Financial Independence Ratio, Effectiveness Ratio of Regional Original Income, and the Degree Ratio of Fiscal Decentralization, but the Regional Financial Dependency Ratio does not optimize income from other sectors, resulting the level of dependence on funds transfers are still very high and the Efficiency Ratio is less efficient because the regional expenditure is greater than the regional income received.
\end{abstract}

Keywords: Budget Realization, Financial Performance, Regional Revenue and Expenditure Budget (APBD)

\section{PENDAHULUAN}

Indonesia mengalami perkembangan teknologi yang semakin pesat khususnya pada bidang akuntansi sangat diperlukan dalam berbagai sektor pekerjaaan salah satunya dalam sektor pemerintah. Dalam sektor pemerintahan akuntansi berperan penting untuk 
menganalisis pelaksanaan tindakan entitas pelapor guna memperlancar fungsi perencanaan, pengelolaan dan pengendalian seluruh dana, kewajiban, dan harta kekayaan untuk kepentingan masyarakat. Dengan demikian, pemerintah daerah maupun pusat memberikan kesejahteraan bagi masyarakat daerah tersebut, respon yang dilakukan akan berguna untuk tata kelola dalam lingkungan pemerintah daerah ataupun untuk daerah itu sendiri.

Demi mempercepat kesejahteraan masyarakat, pemerintah pusat mewujudkan pemberian oronomi daerah. Menurut Undang-Undang Dasar Republik Indonesia No. 23 Tahun 2014, dalam struktur Negara Kesatuan Republik Indonesia, otonomi daerah adalah hak, wewenang, dan kewajiban daerah otonom untuk mengurus dan mengatur sendiri urusan pemerintahan dan kepentingan masyarakat setempat. Adanya otonomi daerah diharapkan pemerintah dapat meningkatkan inovasi dan kreatifitas dalam mengelola keuangan, terutama dalam merealisasikan Anggaran Pendapatan dan Belanda Daerah (APBD). APBD yang sudah disahkan diatur dalam Peaturan Pemerintah Pasal 26 Nomor 12 tahun 2019. APBD adalah pengantar dari pengelolaan anggaran daerah pada periode stu tahun didasarkan dari undang-udang tentang keuangan. Menurut Sujarweni (2016), APBD adalah rencana keuagan tahunan yang disusun oleh pemerintah daerah dan disetujui oleh DPRD.

Terdapat komposisi baru dalam APBD menurut Sartika et al. (2017), pendapatan dipisahkan menjadi tiga kategori, yaitu pendapatan asli daerah (PAD), dana perimbangan, dan pendapatan lain-lain yang sah. Selain itu,belanja dibagi menjadi empat bagian, yaitu belanja aparatur daerah, belanja pelayanan publik, belanja bagi hasil dan bantuan keuangan, dan belanja tidak terduga. Belanja aparatur daerah diklasifikasikan menjadi tiga kategori, yaitu belanja operasi dan pemeliharaan, belanja modal/pembangunan, serta belanja administrasi umum. Belanja pelanyanan publik juga dikelompokan menjadi tiga, yaitu belanja operasi dan pemeliharaan, belanja administrasi umum, dan belanja modal.

Kemampuan daerah dalam mengelola keuangan dan menjalankan otonomi daerah, salah satunya dapat ditentukan oleh kinerja keuangan daerah, yaitu dengan menganalisa laporan pemerintah seperti Laporan Realisasi Anggaran (LRA). Pengukuran kinerja keuangan sangat penting untuk menilai akuntabilitas pemerintah daerah dalam mengelola anggaran daerah. Hal ini dilakukan melalui laporan keuangan, yang bertujuan untuk memberikan informasi tentang status keuangan pemerintah daerah, realisasi anggaran, dan kinerja keuangan yang berguna dalam pengambilan keputusan dan menunjukkan akuntabilitas sumber daya pelaporan. Evaluasi kinerja berupa analisis rasio keuangan yang bersumber dari aspek Laporan Pertanggungjawaban Kepala Daerah berupa perhitungan APBD (Sijabat et al., 2014).

Pemerintah Indonesia melakukan pelaksanaan anggaran dengan dua fungsi, yaitu dungsi perbendaharaan (entitas pelaporan) dan fungsi pelaksana anggaan (entitas akuntansi). Entitas pelaporan sendiri adalah pemerintah daerah, pemerintah pusat, dan Lembaga yang menurut perundang-undangan diharuskan Menyusun laporan keuangan. Sementara entitas akuntansi didefinisikan sebagai satuan kerja dari mulai tingkat lembga/kementrian sampai ke tingkat Unit Pelayanan Teknis (UPT) untuk pemerintah daerah, dan untuk pemrintah pusat dari mulai badan/Lembaga/dinas sampai tingkat UPT dan Kecamatan.

Menurut analisis Anim Rahmayati (2016), kinerja keuangan Pemerintah Kabupaten Sukoharjo masih dibawah stanndar. Meskipun pengelolaan PAD secara kompeten dan efesien, tingkat kemandirian daerah masih cukup rendah. Dan dalam penelitian Nurhayati (2015) menunjukkan bahwa pada Kabupaten Rokan Hulu rasio kemandirian keuangan masih 
sangat rendah, rasio ketergantungan masih sangat tinggi dan belum optimal, rasio efektivitas sangat efektif, rasio aktivitas belanja rutin sangat renah sedangkan belanja pembangunan sangat tinggi, rasio pertumbuham kategori cukup baik.

Pada tahun 2017, Kota Bogor menerima opini Wajar Tanpa Pengcualiaan (WTP) dari Badan Pemeriksaan Keuangan (BPK) terkait pelaporan keuangan tahun anggran 2016. Jkika laporan keuangan bebas dari salah saji yang selius, maka opini WTP akan dikeluarkan. Audit meyakini bahwa pemerintah telah menerapkan standar akuntansi berlaku umum dengan baik, berdasarkan informasi audit yang diterima.

Dari informasi tersebut dapat dijelaskan bahwa jumlahpenduduk miskin di Kota Bogor mengalami penurunan dari tahun 2014 yaitu 7,74\% dan pada tahun 2018 menjadi 5,93\%. Peningkatan anggaran penanggulangan kemiskinan teus meingkai, pada tahun 2018 jumlahnya mencapai Rp. 426 miliar, selaras terjadinya penurunan jumalah penduduk. Di antara beberapa program penanggulangan kemiskinan yaitu dengan adanya JKN bagi masyarakat kurang mampu dan ditahun 2018 telah mencapai 95,85\%. Pencapaian tersebut didukung dengan terus meningkatnya cakupan pelayanan Kesehatan dasar dan rujukan bagi masyarakat miskin yang mencapai $79,5 \%$ pada tahun 2018 , presentase penduduk miskin yang terlayani di RSUD Kota Bogor mencapai 90,11\% dan kunjungan dokter ke keluarga kurang mampu mencapai $93 \%$.

Tabel 1 PAD Kota Bogor Tahun 2014-2019

\begin{tabular}{|c|c|}
\hline Tahun & Jumlah \\
\hline 2014 & Rp544,835,708,254.00 \\
\hline 2015 & Rp627,597,050,141.00 \\
\hline 2016 & Rp783,873,587,219.00 \\
\hline 2017 & Rp978,197,741,947.33 \\
\hline 2018 & Rp912,197,971,288.85 \\
\hline 2019 & Rp1,015,884,216,919.86 \\
\hline
\end{tabular}

Sumber data: https://ppid.kotabogor.go.id/

Penjelasan tersebut menunjukkan bahwa Pendaptan Asli Daerah (PAD) Kota Bogor mengalami peningkatan dari tahun 2014 hingga 2019. Namun, pada tahun 2018 PAD Kota Bogor mengalami penurunan. Hal ini dikarenakan terjadinya penurunan pendapatan retribusi daerah, pendapatan asli daerah yang sah, dan pendapatan hasil pengelolaan kekayaan daerah yang dipisahkan. Pendapaan Asli Daerah (PAD) Kota Bogor paling tinggi berada di tahun 2019.

Dalam hal ini Kota Bogor mengalami penuruna tingkat kemiskinan penduduk pada thu 2014-2019 dengan memajukan Pendapatan Asli Daerah (PAD). Berdasarkan uraikan yang telah dijelaskan diatas, penulis ingin mengetahui mengenai kinerja keuangan pemerintah daerah dalam laporan realiasasi anggaran pendapatan dan belanja daerah kota bogor tahun 2014-2019.

Berdasarkan uraian latar belakang diatas, maka rumusan masalah yang diangakat yaitu tentang bagaimana menganalisis kinerja keuangan pendapatan dan belanja Pemerintah Daerah dan Kota Bogor pada tahun anggaran 2014-2019. Batasan masalah pada penelitian ini membatasi pada kineja keuangan daeralah dalam mengelola dan belanja daerah. Objek 
penelitiannya yaitu Kinerja Keuangan Pemeritah Daerah, Pemerintah Daerah Kota Bogar sebgai subjek. Unit peneltian ini adalah Laporan Realisasi Anggaran tahun 2014-2019. Kinerja keuangan daerah dianalisis menggunakan rasio kemandirian, rasio derajat desentralisasi fiskal, rasio ketergantungan, rasio efektivitas pendapatan asli daerah dan rasio efesiensi keuangan daerah.

Berdasarkan rumusan masalah tersebut, maka tujuan dari penelitian ini adalah untuk mengetahui dan menilai kinerja keuangan dalam Laporan Realisasi Anggaran Pemerintah Kota Bogor Tahun 2014-2019.

\section{LANDASAN TEORI}

\subsection{Akuntansi Pemerintah}

Akuntansi Pemerimntah bertujuan untuk melakukan aktivitas pencatatatan, pengklasifikasian, pengikthisaran, dan pelaporan. Transaksi-transaksi keuangan pemerintah adalah objek akuntansi sebagai implikasi dari pelaksanaan APBN/APND, selain itu tujuan akuntansi pemerintah yaitu laporan keuangan pemerintah yang merupakan laporan pertanggungjawaban dari pelaksanaan APBN dan APBD.

\subsection{Otonomi Daerah}

Otonomi daerah sebagai kekuasaan atau wewenang pada suatu daerah atau wilayah yang mengelola dan mengatur kepentingan wilayah/daerah masyarakat itu sendiri. Pengertian otonomi daerah secara luas yaitu sebagai wewewang atau kekeuasaan pada suatu wilayah/daerah yang mengatur dan mengelola untuk kepentingan masyarakat itu sendiri mualai daei politik, ekonomi, dan pengaturan perimbangan keuangan termasuk pengaturan budaya, ideologi, dan sosial, dan budaya yang sesuai dengana tradisi adat istiadat daerah.

\subsection{Anggaran Pendapatan dan Belanja Daerah (APBD)}

APBD merupakan ujud dari rencana jangka panjang daerah sera rencana jangka menengah yang dibuat dari visi dan misi kepala daerah. APBD proses dari rencana pendapatan, belanja daerah dan pembiayaan untuk satu tahu. APBD dipersiapkan oleh pemerintah daerah, kemudia dibahas dan disetujui oleh Dewan Perwakilan Rakyat Daerah sehingga pada akhirnya merupakan produk hokum berupa Peraturan Daerah yang harus diikuti lembaga daerah. Semua penerimaan dan pengeluaran daerah harus dicatat dan dikelola pada APBD.

\subsection{Laporan Keuangan Pemerintah Daerah}

Laporan keuangan adalah produk manajemen dalam melakukan pertanggungjawabban penggunaan sumber daya dan sumber dana yang dopercayakan. Laporan keuangan secara umum, menyediakan informasi tentang kinerja, posisi keuangan dan arus kass dalam suatu periode. Laporan ini ditujukan bagi pengguna laporan di luar pemerintah daerah untuk menilai maupun mengambil keputusan. Sumber informasi yang dimaksud adalah pemerintah daerah yang bersangkutan. Laporan keuangan harus disajikan secara transparan, mudah dipahami, wajar, dan dapat dibandingkan dengam tahun sebelumnya ataupun pemerintah daerah lain. 


\section{METODE PENELITIAN}

\subsection{Objek dan Subjek Penelitian}

Objek penelitian ini adalah Kinerja Keuangan Pemerintah Daerah. Subjek penelitian ini adalah Pemerintah Daerah Kota Bogor. Dan Laporan Realisai Anggaran tahun 2014-2019 sebagai unit penelitian.

\subsection{Jenis dan Sumber Data}

Data kuantitatif adalah jenis data yang digunakan dalam penelitian ini, yaitu data berupa Laporan Realisasi Anggaran tahun anggaran 2014-2019 Pemerintah Kota Bogor. Sumber data yang digunakan adalah sumber data sekunder yang diperoleh secara tidak langsung melalui media Pemerintah Kota Bogor. Data Sekunder tersebut berupa Laporan Realisai Anggaran yang dipublikasi untuk umum yang diperoleh dari website resmi Kota Bogor yaitu https://ppid.kotabogor.go.id/

\subsection{Teknik Analisis}

Topik yang akan dijadikan penelitian terkait dengan kinerja keuangan Pemerintah Kota Bogor tahun 2014-2019, dan dilakuakan dengan teknik metedologi analisis data deskiptif kuantitatif untuk menjawab rumusan masalah. Pada penelitian ini juga menggunakan alat analisis sebagai berikut:

1. Rasio Kemandirian

Rasio kemandirian mencerminkan ketergantungan daerah pada sumber pembiayaan eksternal. Semakin besar rasio kemandirian maka semakin rendah tingkat ketergantungan daerah pada bantuan eksternal (terutama pemerintah provinsi dan pusat) (Halim \& Kusufi, 2012).

$$
\text { Rasio Kemandirian }=\frac{P A D}{\text { Pendapatan transfer }} \times 100 \%
$$

Tabel 2 Pola Hubungan dan Tingkat Daerah

\begin{tabular}{|c|c|c|}
\hline Rasio Kemandirian & Kemampuan Keuangan & Pola Hubungan \\
\hline $0 \%-25 \%$ & Rendah Sekali & Instruktif \\
\hline $25 \%-50 \%$ & Rendah Sekali & Konsultif \\
\hline $50 \%-75 \%$ & Sedang & Partisipatif \\
\hline $75 \%-100 \%$ & Tinggi & Delegatif \\
\hline
\end{tabular}

2. Rasio Derajat Desentralisasi Fiskal

Rasio derajat desentralisai diukur dengan metode dibandingkannya antara jumlah Pendapatan Asli Daerah dengan Penerimaan Daerah. Semakin bear PAD nya, maka semakin besar kemampuan pemerintah dalam melaksanakan desentralisasi.

$$
\text { Rasio Desentralisasi Fiskal }=\frac{\text { Pendapatan Asli Daerah }}{\text { Total Pendapatan Daerah }} \times 100 \%
$$


Tabel 3 Skala Interval Rasio Derajat Desentralisasi Fiskal

\begin{tabular}{|c|c|}
\hline Skala Interval Rasio Derajat & Kemampuan Keuangan Daerah \\
\hline $00,00-10,00$ & Sangat Kurang \\
\hline $10,01-20,00$ & Kurang \\
\hline $20,01-30,00$ & Sedang \\
\hline $30,01-40,00$ & Cukup \\
\hline $40,01-50,00$ & Baik \\
\hline$<50,00$ & Sangat Baik \\
\hline
\end{tabular}

3. Rasio Ketergantungan Keuangan Daerah

Rasio ini diukur dengan metode dibandingkannya anatara jumlah pemasukan anggaran ditransfer daerah yang di peroleh dengan total daerah yang diterima (Mahmudi, 2016). Semakin rendah nilainya, maka semakin bagus kinerja pemerintahnya.

$$
\text { Rasio Ketergantungan }=\frac{\text { Pendapatan transfer }}{\text { Total Pendapatan Daerah }} \times 100 \%
$$

Tabel 4 Kriteria Rasio Ketergantungan Keuangan Daerah

\begin{tabular}{|c|c|}
\hline $\begin{array}{c}\text { Skala Pendapatan Transfer } \\
\text { Terhadap Total Pendapatan }\end{array}$ & $\begin{array}{c}\text { Ketergantungan Keuangan } \\
\text { Daerah }\end{array}$ \\
\hline $00,00-10,00$ & Sangat Rendah \\
\hline $10,01-20,00$ & Rendah \\
\hline $20,01-30,00$ & Sedang \\
\hline $30,01-40,00$ & Cukup \\
\hline $40,01-50,00$ & Tinggi \\
\hline$<50,00$ & Sangat Tinggi \\
\hline
\end{tabular}

4. Rasio Efektivitas

Rasio Evektivitas PAD menggambarkan kemampuan pemerintah daerah dalam merealisasikan PAD yang direncanakan dibandingkan dengan target yang ditetapkan berdasarkan potensi daerah sebenarnya (Mahmudi, 2016).

$$
\text { Rasio Efektivitas }=\frac{\text { Realisasi } P A D}{\text { Anggaran } P A D} \times 100 \%
$$

Tabel 5 Kriteria Rasio Efektivitas PAD

\begin{tabular}{|c|c|}
\hline Presentase Efektivitasa & Kriteria Efektivitas \\
\hline$>100 \%$ & Sangat efektif \\
\hline $90-100$ & Efektif \\
\hline $80-90$ & Cukup efektif \\
\hline $60-80$ & Kurang efektif \\
\hline$<60$ & Tidak efektif \\
\hline
\end{tabular}


5. Rasio Efisiensi Keuangan Daerah

Rasio Efisiensi diukur dengan dibandingkan antara banyaknya tarif yang dibelanjakan untuk mendapatkan pendapatan dengan realisasi penerimaan pendapatan (Mahmudi, 2016). Semakin renah nilainya, maka semakin bagus kinerja pemerintahnya.

$$
\text { Rasio Efisiensi }=\frac{\text { Realisasi Belanja Daerah }}{\text { Realisasi Pendapatan Daerah }} \times 100 \%
$$

Tabel 6 Rasio Efisiensi Keuangan Daerah

\begin{tabular}{|c|c|}
\hline Kriteria Efisiensi & Persentase Efisiensi \\
\hline$>100 \%$ & Tidak efisien \\
\hline $90-100$ & Kurang efesien \\
\hline $80-90$ & cukup efisien \\
\hline $60-80$ & efesien \\
\hline$<60$ & sangat efisien \\
\hline
\end{tabular}

\section{HASIL DAN PEMBAHASAN}

Berikut ini adalah analisis yang digunakan untuk menilai kinerja keuangan Pemerintah Kota Bogor yang diukur menggunakan beberapa alat analisis, yaitu:

\subsection{Rasio Kemandirian Keuangan Daerah}

Tabel 7 Rasio Kemandirian Keuangan Daerah Kota Bogor Tahun 2014-2019

\begin{tabular}{|c|c|c|c|c|c|}
\hline Tahun & Jumlah & \multicolumn{2}{|c|}{ Pendapatan Transfer } & $\begin{array}{c}\text { Rasio } \\
\text { Kemandirian } \\
\text { Keuangan } \\
\text { Daerah (\%) }\end{array}$ & $\begin{array}{c}\text { Kemampuan } \\
\text { Keuangan/Pola } \\
\text { Hubungan }\end{array}$ \\
\hline 2014 & $\mathrm{Rp} 544,835,708,254.00$ & $\mathrm{Rp} \quad 1,188,391,596,875.00$ & $45,85 \%$ & Rendah/Konsultif \\
\hline 2015 & $\mathrm{Rp} 627,597,050,141.00$ & $\mathrm{Rp} \quad 1,218,375,878,985.00$ & $51,51 \%$ & Sedang/Partisipatif \\
\hline 2016 & $\mathrm{Rp} 783,873,587,219.00$ & $\mathrm{Rp} \quad 1,297,444,479,820.00$ & $60,42 \%$ & Sedang/Partisipatif \\
\hline 2017 & $\mathrm{Rp} 978,197,741,947.33$ & $\mathrm{Rp} \quad 1,293,505,562,261.00$ & $75,62 \%$ & Tinggi/Delegatif \\
\hline 2018 & $\mathrm{Rp} 912,197,971,288.85$ & $\mathrm{Rp}$ & $1,303,332,063,609.00$ & $69,99 \%$ & Sedang/Partisipatif \\
\hline 2019 & $\mathrm{Rp} 1,015,884,216,919.86$ & $\mathrm{Rp} 1,455,644,350,874.00$ & $69,79 \%$ & Sedang/Partisipatif \\
\hline \multicolumn{7}{|c|}{ Rata-Rata } & $62,20 \%$ & Sedang/Partisipatif \\
\hline
\end{tabular}

Sumber Data : Data Diolah, 2021

Berdasarkan hasil perhitungan pada tabel diatas, Rasio Kemandirian Daerah Kota Bogor pada tahun 2014-2019 dikatakan sedang dengan pola hubungan Partisipatif dengan rasio $62,20 \%$ yang berarti peranan pemerintah pusat sudah mulai berkurang, mengingat daerah yang bersangkutan tingkat kemandiriannya mendekati mampu melaksanakan urusan 
otonomi daerah. Tingkat kemandirian terendah adalah $45,85 \%$ pada tahun 2014 , sedangkan tinglat kemandirian tertinggi adalah 75,62\% pada tahun 2017.

Pada penelitian Mutiha (2016) anggaran pada Kota Bogor tahun 2010-2014 menunjukkan rasio kemandirian perananan pemerintah pusat masih lebih dominan dengan polah hubungan konsultatif sebesar 31,89\%. Penelitian sebelumnya yang dilakukan oleh Ramadhani (2016) anggaran Kota tararan tahun 2010-2015 melalui perhitungan rasio kemandirian menunjukkan pola hubungan sampai ke pola hubungan delegative dimana masih mandiri dalam melakukan otonomi daerah.

\subsection{Rasio Derajat Desentralisasi Fiskal}

Tabel 8 Rasio Derajat Desentralisasi Kota Bogor Tahun 2014-2019

\begin{tabular}{|c|c|c|c|c|c|}
\hline Tahun & $\begin{array}{c}\text { Pendapatan Asli } \\
\text { Daerah (PAD) }\end{array}$ & Total Pendapatan Daerah & Rasio\% & $\begin{array}{c}\text { Tingkat } \\
\text { Desentralisasi } \\
\text { Fiskal }\end{array}$ \\
\hline 2014 & $\mathrm{Rp} 544,835,708,254.00$ & $\mathrm{Rp} 1,757,697,381,840.00$ & $31,00 \%$ & Cukup \\
\hline 2015 & $\mathrm{Rp} 627,597,050,141.00$ & $\mathrm{Rp}$ & $1,913,210,404,036.00$ & $32,80 \%$ & Cukup \\
\hline 2016 & $\mathrm{Rp} 783,873,587,219.00$ & $\mathrm{Rp}$ & $2,152,370,082,886.00$ & $36.42 \%$ & Cukup \\
\hline 2017 & $\mathrm{Rp} 978,197,741,947.33$ & $\mathrm{Rp} 2,289,359,362,675.00$ & $42,47 \%$ & Baik \\
\hline 2018 & $\mathrm{Rp} 912,197,971,288.85$ & $\mathrm{Rp} 2,328,703,432,668.85$ & $39,17 \%$ & Cukup \\
\hline 2019 & $\mathrm{Rp} 1,015,884,216,919.86$ & $\mathrm{Rp} 2,559,857,207,793.86$ & $39,69 \%$ & Cukup \\
\hline \multicolumn{7}{|c|}{ Rata-Rata } & $36,97 \%$ & Cukup \\
\hline
\end{tabular}

Sumber Data : Data Diolah, 2021

Berdasarkan hasil perhitungan pada tabel diatas, Rasio Derajat Desentralisasi Kota bogor pada tahun 2014-2019 dapat dikatakan cukup yaitu dengan rasio diatas 30\%. Hal ini disebabkan karena adanya peningkatan pada Pendapatan Asli Daerah Kota Bogor setiap tahummya. Derajat Desentralisasi tertinggi terjadi pada tahun 2017 yaitu dengan rasio $42.73 \%$ sedangkan derajat desentralisasi terendah terjadi pada tahun 2014 yaitu dengan rasio $31,00 \%$. Dengan hal tersebut, rata-rata derajat desentralisasi Kota Bogor adalah sebesar $36,97 \%$ dikatakan cukup.

Pada Penelitian terdahulu di Kabupaten Belu menyatakaan bahwa dalam perhitungan Rasio Desentralisasi Fiskal pada tahun 2008 sampai dengan tahun 2018 dikategorikan masih sangat kurang dalam membiayai pembangun daerah, hal ini dapat diketahui bahwa rasio ketergantungan yang sangat tinggi pada pemerintah pusat yaitu dengan rasio 82,29\% (Oki et al., 2020).

Penelitian sebelumnya juga dilakukan di Provinsi Sulawesi Utara melalui perhitungan Rasio Desentralisasi Fiskal pada tahun 2014-2019 menunjukan bahwa masih sangat kurang dikarenakan rata-rata rasionya berada di interval $<25 \%-50 \%$. Hal ini dikarenkan kontribusi kenaikan PAD yang kecil dibandingan dengan total pendapatan daerah (Manueke, 2020). 


\subsection{Rasio Ketergantungan Keuangan Daerah}

Tabel 9 Rasio Ketergantungan Daerah Kota Bogor Tahun 2014-2019

\begin{tabular}{|c|cc|cc|c|c|}
\hline \multirow{2}{*}{ Tahun } & \multicolumn{2}{|c|}{ Pendapatan Transfer } & Total Pendapatan Daerah & Rasio (\%) & Ketergantungan \\
& & & & & & \\
\hline 2014 & $\mathrm{Rp}$ & $1,188,391,596,875.00$ & $\mathrm{Rp}$ & $1,757,697,381,840.00$ & $67,61 \%$ & Sangat Tinggi \\
\hline 2015 & $\mathrm{Rp}$ & $1,218,375,878,985.00$ & $\mathrm{Rp}$ & $1,913,210,404,036.00$ & $63,68 \%$ & Sangat Tinggi \\
\hline 2016 & $\mathrm{Rp}$ & $1,297,444,479,820.00$ & $\mathrm{Rp}$ & $2,152,370,082,886.00$ & $60,28 \%$ & Sangat Tinggi \\
\hline 2017 & $\mathrm{Rp}$ & $1,293,505,562,261.00$ & $\mathrm{Rp}$ & $2,289,359,362,675.00$ & $56,50 \%$ & Sangat Tinggi \\
\hline 2018 & $\mathrm{Rp}$ & $1,303,332,063,609.00$ & $\mathrm{Rp}$ & $2,328,703,432,668.85$ & $55,97 \%$ & Sangat Tinggi \\
\hline 2019 & $\mathrm{Rp}$ & $1,455,644,350,874.00$ & $\mathrm{Rp}$ & $2,559,857,207,793.86$ & $56,86 \%$ & Sangat Tinggi \\
\hline \multicolumn{7}{|c|}{ Rata-Rata } \\
\hline
\end{tabular}

Sumber Data : Data Diolah, 2021

Berdasarkan tabel 9. Dapat dilihat bahwa rasio ketergantungan keuangan daerah Pemerintah Kota Bogor untuk lima tahun terakhir sangat tinggi dengan presentasi rasio ratarata yaiu 6-,15\%. Sejak tahun 2014 rasio ketergantungan mencapai $67,61 \%$ dan terus mengalami penurunan sampai tahun 2019. Hasil ini menunjukkan angka ketergantungan daerah Kota Bogor sangat tinggi jika dilihat secara keseluruhan selama lima tahun terakhir. Kondisi ini menunjukkan bahwa Pemerintah Kota Bogor masih sangat berganung terhadap pendapatan transfer yang didapatkan dari Pemerintah Pusat dan Pemerintah Provinsi.

Dalam penelitian yang dilakukan Susilawati et al. (2018) di Sleman pada tahun 20112015 hasil perhitungan Rasio Ketergantungan Keuagan Daerah masih dikatakan sangat bergantung pada pemerintah pusat dengan rasio 73,86\%. Total pendaptan daerah masih banyak bersar dari pendapatan transger, yang artinya Pemerintah Kabupaten Sleman belum mampu memaksimalkan PAD dalam memperoleh pendapatan daerah.

\subsection{Rasio Efektivitas Pendapatan Daerah}

Tabel 10 Rasio Efektivitas Pendapatan Kota Bogor Tahun 2014-2019

\begin{tabular}{|c|c|cc|c|c|}
\hline \multirow{2}{*}{ Tahun } & Realisasi PAD & & Anggaran PAD & $\begin{array}{c}\text { Tingkat } \\
\text { Rasio } \\
(\%)\end{array}$ & Efektivitas \\
\hline 2014 & $\mathrm{Rp} 544,835,708,254.00$ & $\mathrm{Rp}$ & $483,014,420,704.00$ & $112,80 \%$ & Sangat Efetif \\
\hline 2015 & $\mathrm{Rp} 627,597,050,141.00$ & $\mathrm{Rp}$ & $627,815,080,243.00$ & $99,97 \%$ & Efektif \\
\hline 2016 & $\mathrm{Rp} 783,873,587,219.00$ & $\mathrm{Rp}$ & $728,030,823,933.00$ & $107,67 \%$ & Sangat Efektif \\
\hline 2017 & $\mathrm{Rp} 978,197,741,947.33$ & $\mathrm{Rp}$ & $917,788,606,450.00$ & $106,58 \%$ & Sangat Efektif \\
\hline 2018 & $\mathrm{Rp} 912,197,971,288.85$ & $\mathrm{Rp}$ & $887,396,041,682.00$ & $102,79 \%$ & Sangat Efektif \\
\hline 2019 & $\mathrm{Rp} 1,015,884,216,919.86$ & $\mathrm{Rp}$ & $972,607,288,978.00$ & $104,45 \%$ & Sangat Efektif \\
\hline & \multicolumn{7}{|c|}{ Rata-Rata } & & $105,71 \%$ & Sangat Efektif \\
\hline
\end{tabular}

Sumber Data : Data Diolah, 2021 
Berdasarkan pada tabel diatas dapat dikatakan bahwa rasio efektivitas Pendapatan Kota Bogor tahun anggaran 2014-2019 dikatakan sangat efektif karena rasionya berada diatas $100 \%$. Rasio efektifitas tertinggi berada pada tahun 2014 yaitu $112,80 \%$ sedangkan rasio efektivitas terendah berada pada tahun 2015 yaitu 99,97\% . Untuk rata-rata rasio efektivitas Kota Bogor pada tahun 2014-2019 yaitu 105,71\% dikatakan sangata efektif. Hal ini menunjukkan bahwa Pemerintah Kota Bogor mampu meningkatkan dan mengelola dengan sangat efektif dalam PAD melalui sektro pajak daerah, retribusi daerah, hasil pengelolaan kekayaan daerah yang dipisahkan dan lain-lain pendapatan asli daerah yang sah.

Pada penelitian Susanto (2019) di Kota Mataram dalam perhitungan rasio efektivitas pendapatan daerah tahun 2012 sampai dengan tahun 2015 dikategorikan efektif karena presentase diatas seratus, yaitu sebesar 101,81. Hal ini menggambarkan bahwa efektivitas pada Pemerintah Daerah Kota Mataram saat merealisasikan sumber PAD dangat efektif berdasarakan penilaian efektivitas.

\subsection{Rasio Efisiensi}

Tabel 11 Rasio Efesiensi Kota Bogor Tahun 2014-2019

\begin{tabular}{|c|cc|cc|c|c|}
\hline Tahun & Realisasi Belanja Daerah & \multicolumn{2}{c|}{$\begin{array}{c}\text { Realisasi Pendapatan } \\
\text { Daerah }\end{array}$} & $\begin{array}{c}\text { Rasio } \\
\text { (\%) }\end{array}$ & $\begin{array}{c}\text { Tingkat } \\
\text { Efektivitas }\end{array}$ \\
\hline 2014 & $\mathrm{Rp}$ & $1,702,962,476,448.00$ & $\mathrm{Rp}$ & $1,757,697,381,840.00$ & $96,89 \%$ & Kurang Efesien \\
\hline 2015 & $\mathrm{Rp}$ & $1,862,982,871,234.00$ & $\mathrm{Rp}$ & $1,913,210,404,036.00$ & $97,37 \%$ & Kurang Efesien \\
\hline 2016 & $\mathrm{Rp}$ & $2,115,296,888,270.00$ & $\mathrm{Rp}$ & $2,152,370,082,886.00$ & $98,28 \%$ & Kurang Efesien \\
\hline 2017 & $\mathrm{Rp}$ & $2,245,590,002,913.62$ & $\mathrm{Rp}$ & $2,289,359,362,675.00$ & $98,09 \%$ & Kurang Efesien \\
\hline 2018 & $\mathrm{Rp}$ & $2,406,586,936,843.04$ & $\mathrm{Rp}$ & $2,328,703,432,668.85$ & $103,34 \%$ & Tidak Efesien \\
\hline 2019 & $\mathrm{Rp}$ & $2,528,500,802,938.19$ & $\mathrm{Rp}$ & $2,559,857,207,793.86$ & $98,78 \%$ & Kurang Efesien \\
\hline \multicolumn{7}{|c|}{ Rata-Rata } \\
\hline
\end{tabular}

Sumber Data : Data Diolah, 2021

Berdasarkan data tabel diatas dapat diketahui bahwa rata-rata ratio selama tahun 20142019 untuk rasio efisiensi Kota Bogor 98,79\% dengan kriteria kurang efesien. Pada tahun 2018 , kriteria yang didapatkan adalah tidak efisien dengan ratio 103,34\%. Hal ini disebabkan karena realisasi belanja daerah Rp2.406.586.936.843,04 dan realisasi pendapatan daerah Rp2.328.703.432.668,85 sehingga menyebabkan tidak efisiennya belanja daerah yang lebih besar daripada pendapatan daerah yang diterima.

Pada penelitian terdahulu di Kota Jayapura pada tahun 2011 sampai dengan 2017 dalam perhitungan rasio efesiensi sudah dikatakan sangat efesien karena perbandingan anatara realisasi penerimaan PAD dengan biaya pemungutan PAD nilainya berkisar $<5 \%$. Hal ini menunjukkan bahwa hasil pemungutan PAD lebih besar dibandinkan dengan biaya untuk memperoleh PAD (Tanan \& Duri, 2018).

Penelitian sebelumnya juga dilakukan di Kabupaten Gunung Kidul tahun 2010 sampai dengan 2014, melalui perhitungan rasio efesiensi keuangan daerah dikatakan belum efesien 
karena skalanya diatas $100 \%$. Rata-rata efesiensi yang terjadi selama limat tahun yaitu 109,8\% (Fathah, 2017).

\section{KESIMPULAN}

Berdasarkan hasil analisis data anggaran dan pendapatan belanja daerah Kota Bogor pada tahun 2014-2019, maka dapat disimpulkan bahwa kinerja Keuangan Pemerintah Kota Bogor sebagai berikut:

1. Rasio Kemandirian Pemerintah Kota Bogor selama tahun 2014-2019 meliliki tingkat kemandirian sedang, dengan nilai rata-rata rasio sebear 62,20\%. Hal ini dapat dikatakan tingkat kemandirian Kota Bogor tahun 2014-2019 sudah mampu melakakukan urusan otonomi daerahnya karena peranan pemerintahan pusat sudah mulai berkurang.

2. Rasio Derajat Desntralisasi Fiskal Pemerintah Kota Bogor selama tahun 2014-2019 dikatakan cukup, dengan nilai rata-rata rasio sebesar 36,42\%. Hal ini dapat dikatakan Pemerintah Kota Bogor mampu melaksanakan pembangunan daerah dengan mengkatkan PAD setiap tahunnya.

3. Rasio Ketergantungan Keuangan Daerah Kora Bogor selama tahun 2014-2019 yaitu sangat tinggi, dengan nilai rata-rata rasio sebesar 60,15\%. Halini dapat dikatakan Pemerintah Kota Bogor masih memiliki ketergantungan terhadap penerimaan pemerintah pusat.

4. Rasio Efektivitas Pemerintah Kota Bogor selama tahun 2014-2019 dikatakan sangat efektif, dengan nilai rata-rata rasio sebesar $105,71 \%$. Hal ini dapat dikatakan kemampuan Pemerintah Daerah dalam merealisasikan pendapatan asli daerah yang direncanakan dibandingkan dengan target yang ditetapkan berdasarkan potensi riil daerah.

5. Rasio Efesiensi Pemerintah Kota Bogor selama tahun 2014-2019 dikatakan kurang efesien, dengan nilai rata-rata rasio efesienso sebesar 98,79\%. Hal ini dapat dikatakan masih besarnya realisai biaya yang dikeluarkan daripada realisasi pendapatan yang diterima.

\section{Saran}

1. Bagi Pemerintah Darah Kota Bogor

Setelah melakukan penelitian ini, penulis menyarankan agar kinerja Pemerintah Kota Bogor terus melakukan peningkan dan memaksimalkan Pendapatan Asli Daerah. Jika dilihar dari Rasio Ketergantungan maka Pemerintah Daerah Kota Bogor harus lebing menggali potensi daerahnya dalam sektor pendapatan agar PAD yang didapat lebih meningkan sehingga tidak perlu mendapat dana transfer yang sangat besar daru Pemerintah Provinsi maupun Pemerinah Pusat. Berdasarkan Rasio efesiensi, Pemerintah Darah Kota Bogor masih kurang efesien dalam merealisaikan pendapatan daerahnya karena masih mengeluarkan dana belanja daerah yang begitu besar. Seharusnya Pemerintah Kota Bogor dapat mengurangi realisasi belanja daerahnya seperti belanja modal dan belanja operasi agar dapat memaksimalkan realisasi pendapatan yang diterima nantinya.

2. Bagi peneliti selanjutnya 
Diharapkan dapat lebih rinci dalam menganalisa Kinerja Keuangan Daerah dengan berbagai macam rasio dan menambah jangka waktu penelitian lebih dari 6 tahun dengan memperluar lingkup wilayah penelitian agar tidak hanya 1 kota saja.

\section{DAFTAR PUSTAKA}

Fathah, R. N. (2017). Analisis Rasio Keuangan untuk Penilaian Kinerja pada Pemerintah Daerah Kabupaten Gunung Kidul. Ebbank, 8(1), 33-48.

Halim, A., \& Kusufi, M. S. (2012). Akuntansi Keuangan Daerah, Edisi Keempat. Jakarta: Penerbit Salemba Empat.

Mahmudi. (2016). Akuntansi sektor publik. UII Press.

Manueke, B. B. R. (2020). Analisis Kinerja Keuangan Daerah Di Provinsi Sulawesi Utara Tahun 2014-2019. Jurnal Akrab Juara, 5(2), 132-146.

Mutiha, A. (2016). Analisis Kinerja Keuangan Pemerintah Daerah Kota Bogor Tahun Anggaran 2010-2014. Jurnal Vokasi Indonesia, 4(2).

Nurhayati, N. (2015). Analisis Rasio Keuangan Untuk Mengukur Kinerja Pemerintah Daerah Kabupaten Rokan Hulu. Cano Ekonomos, 4(1), 55-66.

Oki, K. K., Nalle, F. W., \& Meomanu, P. A. v. (2020). Analisis Kemandirian Keuangan Daerah Kabupaten Belu. Ekopem: Jurnal Ekonomi Pembangunan, 5(2), 1-6.

Rahmayati, A. (2016). Analisis Kinerja Keuangan Pemerintah Daerah Kabupaten Sukoharjo Tahun Anggaran 2011-2013. Eka Cida, 1(1).

Ramadhani, F. R. (2016). Analisis Kemandirian dan Efektivitas Keuangan Daerah di Kota Tarakan Tahun 2010-2015. Jurnal Ekonomi Pembangunan, 14(1), 85-98.

Sartika, N., Kirmizi, K., \& Indrawati, N. (2017). Analisis Faktor-faktor dalam Struktur APBD dan Kinerja Keuangan Daerah yang Mempengaruhi Belanja Modal pada Kabupaten/Kota di Provinsi Riau. Sorot, 12(2), 121-135.

Sijabat, M. Y., Choirul, S., \& Abdul, W. (2014). Analisis Kinerja Keuangan Serta Kemampuan Keuangan Pemerintah Daerah Dalam Pelaksanaan Otonomi Daerah (Studi Pada Dinas Pendapatan Daerah Dan Badan Pengelola Keuangan Dan Aset Daerah Kota Malang Tahun Anggaran (2008-2012). Jurnal Administrasi Publik (JAP), 2(2). https://www.neliti.com/publications/77477/analisis-kinerja-keuangan-sertakemampuan-keuangan-pemerintah-daerah-dalam-pelak

Sujarweni, V. W. (2016). Akuntansi sektor publik teori, konsep, aplikasi.

Susanto, H. (2019). Analisis Rasio Keuangan Untuk Mengukur Kinerja Keuangan Pemerintah Daerah Kota Mataram. Jurnal Distribusi-Jurnal Ilmu Manajemen Dan Bisnis, 7, 81-92.

Susilawati, D., Wardana, L. K., \& Rahmawati, I. F. (2018). Menilai Kinerja Keuangan dengan Analisis Rasio Keuangan: Studi Kasus BKAD Sleman. Jati: Jurnal Akuntansi Terapan Indonesia, 1(2), 91-98.

Tanan, C. I., \& Duri, J. A. (2018). Analisis Rasio Untuk Pengukuran Kinerja Keuangan dan Evaluasi Kinerja Keuangan Pemerintah (Studi Kasus Pemerintah Kota Jayapura). Future: Jurnal Manajemen Dan Akuntansi, 6(1), 91-101. 